\title{
On Progress in the History of Nephrology
}

\author{
Garabed Eknoyan Augusto Antonello Natale G. De Santo Lorenzo Calò \\ Shaul G. Massry
}

The present volume represents the transactions of the Second Congress of the International Association for the History of Nephrology held in Padua, Italy, on October 4-7, 1998, under the auspices of the University of Padua Faculty of Medicine, the Italian Ministro dell'Università e della Ricerca Scientifica e Technologica, the City of Padua, the Province of Padua, and jointly sponsored by the Istituto Italiano per gli Studi Filosofici and the Arturo Borsatti Association for Nephrology.

The International Association for the History of Nephrology (IAHN) was founded in 1994 in response to expressed interest in continuing the tradition initiated at an International Congress on the History of Nephrology held in Naples, Italy, on October 28-30, 1993. The stated purpose of the IAHN is to foster, stimulate, encourage and promote investigation in the history of medicine as it pertains to all aspects related to the kidney and urinary tract. This is a more accurate statement of the objectives of the IAHN than its name implies, for nephrology was clearly foreign to the period of history encompassed in the publications of the IAHN under the title of History of Nephrology. Yet, by any other name, the conceptualization of the functions and diseases of the kidney had a past, developed over time, and continues to unfold as time goes by. After all, the kidney and urinary tract have served a vital function and their diseases have haunted mankind since its existence, while nephrology is but a toddler in the relatively brief history of compartmentalization of disciplines which have been constructed in medicine over the past two centuries. Now that nephrology is part of the accepted medical nomenclature, it does allow one to integrate the historiographic analysis of the conceptual evolution of our understanding of the function and diseases of the kidney and urinary tract.

Having said that, a question concerning the history of nephrology is surely, why do we need it at all? Why search the musty archives of medical history for references to the kidney and urinary tract? The answers are as simple or complicated as one wishes to make them. As individuals, literally everyone, sometime or another, and some more than others, wants to know how did 'it' all get started. As a discipline trained in the sciences, and therefore as seekers of truth, determining these origins is ingrained in the nature of every physician, and actively pursued by those amongst them who have a strong desire to extend intimacy with their discipline. As clinicians who have experienced the thrills of an accurate diagnosis within their practice, knowledge of the history of a disease allows for a strange but pleasing transposition of the other discoverer's world into one's own. As nephrologists operating in a technological age, using the last equipment we did not design, we need the intellectual escape into the humanities to explore by whom and why the equipment and our very discipline came into existence in the first place. It is to fulfil these, as well as a host of other reasons, that we need to know the history of nephrology. Unfortunately, there is an embarrassing disproportion between the meager reference to the kidney in available sources on the

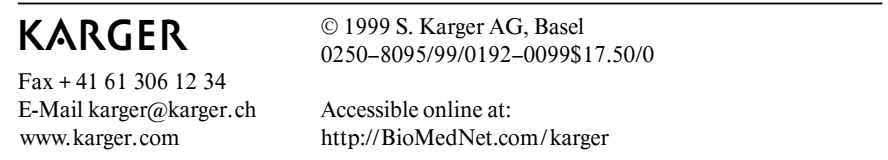


history of medicine and the tremendous scientific achievements that have occurred in nephrology in the brief period of its existence as a discipline. That is why the search must continue to reconstruct our past. That is the purpose of the IAHN. History of Nephrology 3 is another step in that direction.

The inaugural meeting of the IAHN was held on the Island of Kos, Greece, on October 14-16, 1996. In keeping with tradition, the site of the Second Congress was selected because of its historic importance as the home of the medical university which led the renaissance of medicine in the sixteenth century. The meeting would not have been possible without the efforts of the local Organizing Committee, consisting of A. Antonello, A. D'Angelo, S. Favaro, L. Calò, L. Bonfante, S. Cantaro, and the Department of Nephrology of the University of Padua. It was the relentless toil and boundless energy of Augusto Antonello and Lorenzo Calò in attending to every fine detail that ultimately determined the success of the meeting, and created the fond memories with which the congress participants departed. Obviously, individual memories are very personal experiences that even the best analytical psychologist may not be able to unravel. However, there were memorable events in which all participants shared. The first of these was the opening ceremony in the historic Aula Magna (Great Hall) of the University of Padua, lavishly decorated with the old coats of arms of its past illustrious alumni. Appropriately, it is in this august setting that an honorary membership in the IAHN was presented to Avvocato G. Marotta, President of the Istituto Italiano per gli Studi Filosofici, who has been a staunch supporter of the IAHN, beginning with his sponsorhip of the first International Congress on the History of Nephrology in Naples in 1993. Another memorable event that will be cherished by all was the visit to the Anatomy Theatre of Girolamo Fabrici d'Acquapendente (1594), an icon of renaissance medicine which decorates the cover of this volume. Equally memorable was the ambrosial gala dinner at the Ristorante Belle Parti, at which honorary memberships in the IAHN were presented to Professors George Schreiner and Klaus Hierholzer.

The layered depth to the understanding of the history of nephrology that has been generated by the meetings of the IAHN is evident from the contents of the present volume. The presentations made at the congress have been grouped topically for the edited volume. Two of these groupings were planned as special sessions for the meeting. The first is the section on the Contributions of Padua to Nephrology, dedicated to the memory of Professor Arturo Borsatti, Dean of the Medical School of the Uni- versity of Padua. Professor Borsatti was instrumental in the inception of the IAHN and had issued the original invitation for its meeting in Padua. Unfortunately, he passed away in 1995, prior to the first meeting of the IAHN on Kos. His obituary appeared in History of $\mathrm{Ne}$ phrology 2. The other section is the one on the Origins of Renal Physiology. The title and preliminary content of this session was conceived by Professor Carl Gottschalk, a founding Councillor of the IAHN. Unfortunately, Professor Gottschalk passed away unexpectedly two weeks after agreeing to organize the session on the History of Renal Physiology. Professor Klaus Hierholzer was kind enough to assume the responsibility of organizing the session, which is dedicated to the memory of Carl Gottschalk. The session was chaired jointly by its organizer, Klaus Hierholzer, and Professor Gottschalk's beloved wife, Susan Fellner. The list of participants in the session and its content speak for themselves. Professor Stewart Cameron gave the inaugural talk on 'Carl Gottschalk - Physiologist and Historian of Nephrology'. His presentation, eloquent as it was, is but a partial expression of the deep debt of gratitude that the IAHN owes Carl Gottschalk. He, before anyone else, had kindled everyone's interest in the history of nephrology and he, more than anyone else, nurtured its growth in his gentle but relentless support of the IAHN. His wise council on the Board will be missed, but remembered dearly.

At the closing business meeting of the Association, the Board of Directors announced that it had accepted the invitation of Shaul M. Shasha to host the next meeting of the IAHN in Jerusalem, Israel in October of 2000. Also at the business meeting, the following officers were elected to serve for 1998-2000: Shaul G. Massry, President; Spyros Marketos, Vice President; Garabed Eknoyan, Secretary-Treasurer and Luciana Angeletti, Marc E. De Broe, Athanasias Diamandapoulos, Charles George, Shaul M. Shasha, and Sandor Sonkodi as Councillors. In addition, Professor Natale G. De Santo, a founding officer of the IAHN, was elected an ex officio Councillor to serve on the Board of Directors.

In closing, acknowledgements are due to the following organizations, for their generous support of the Second Congress of the IAHN: Associazione Borsatti, Baxter Spa, CISA, Dompè Biotec, Gruppo Iniziative Culturali E Sociali Di Villafranca Padovana, Prodotti Hoechst, Istituto Gentili, Janssen-Cilag, Lofra Cucine, Merck Sharp \& Dohme, Novartis Farma, Sangemini, and Sigma Tau. 